EDITORIAL

Embora o vasto território das ciências médicas tenha compelido os seus cultores a restringir cada vez mais o respectivo campo de aç̧ão criando especializações e subespecializações ad infinitum, a própria filosofia do pensar médico vai impondo de novo e sempre uma versão holística indispensável à compreensão dos problemas particulares da medicina. O mesmo é dizer que, sem uma informação geral contínua do que vai pelo mundo da investigação médica, não pode o insulado especialista descortinar os progressos da sua acanhada comarca. O saber cada vez mais de cada vez menos já não satisfaz o especialista de hoje, receoso de que novos princípios gerais venham afectar o sentido da sua especialização. Sirva de exemplo o advento da imunologia moderna que, subitamente, veio impregnar todos os terrenos da medicina particularizada.

O que se deu no íntimo do cultor da medicina reflectiu-se naturalmente na estrutura das populações científicas. A criação sucessiva de periódicos mais e mais especializados fez reviver a necessidade de publicações multidisciplinares que dessem ao médico constantemente o sentido global dos progressos da medicina.

Nesta senda surgiu a ideia da publicação da Acta Médica Portuguesa, que deseịa ser uma revista de qualidade aberta a todos os sectores médicos intra e extramuros e cobrindo todas as matérias das ciências médicas. Tal fito, porventura ambicioso, tem desde logo a justificá-lo o número crescente de textos portugueses assaz qualificados que procuram abrigo nas páginas das grandes revistas de além fronteiras onde a aceitação é já marca de validez científica. Por seu turno, temos notícia de autores estrangeiros de nomeada que não desdenhariam de ver publicados os seus escritos em periódico português adequado.

Assim, a Acta Médica Portuguesa franqueará as suas portas a todos os textos válidos, escritos em português, inglês, espanhol ou francês, que queiram honrar-nos com a sua colaboração e se conformem com a estrutura e normas desta revista. Um grupo numeroso de consultores científicos de mérito reconhecido assegurará os princípios que nos impusemos.

Para além dos artigos originais, que esperamos constituam o cerne da revista outras seç̧ōes variadas incluirão editoriais, comunicações breves, revisões, casos clínicos, anotações, progressos técnicos, revisões terapêuticas, fichas diagnósticas e técnicas, temas de enfermagem e ciências paramédicas, crítica de livros e informações diversas, destinando-se a dar ao leitor um panorama das ciências médicas actuais.

Também esta revista se decidiu a publicar três suplementos anuais, contribuídos por convite, sobre temas que se anunciarão em tempo oportuno.

Desta feita, a Acta Médica Portuguesa dá início à sua caminhada, onde não faltarão escolhos, mas onde sobrarão os propósitos de bem fazer

\title{
J. Cândido de Oliveira
}

M. Macbado Macedo

A. Sales Luis

A. Galvão-Teles 
Seculo xv1. Greação do ensino anatomico em Lisboa. Dr. Duarte Lopes. Licenciado Pedro Lopes Gardoso.

Resenha analytica da anatomia de Chauliac

Foi sempre notorio - e alguma vez notado com pungente crueza da parte de extrangeiros - 0 atrazo dos estudos anatomicos em Portugal, antes de fins do seculo xvir. E assim é que, certo prefaciador das obras posthumas do grande Malpighi - Pedro Regis, não poz escrupulo em marcar-nos a fogo, com o ferrete de barbaros, n'este trecho candente: "Si itaque verum est, quod vulgo dicitur solatium miserorum esse habere pares, Clarissimus Malpighius, suique similes abunde habent, undeque injurias sibi illatas aequo animo patiantur. Praeterea insignissimi isti viri adversarios quidem ac invidos habuerunt, sed ipsis patroni ac praecones egregii non defuerunt, tandemque invitis malignis, ac improbis, cunctisque remotis obstaculis, gloriam immortalem sibi pepererunt. Eorum opiniones, quae statim rejectae fuerunt et quorum Authores secundum aliquos ignis etiam aeterni poena plectendi erant, hodie florent et in pretio habentur; oppositae vero prorsus damnatae sunt, perpetuaque oblivione obruerentur, nisi essent Hispani, Lusitani, ac Moscovitae, qui in tenebris adhuc versantes, eas inepte fovent., E não sirva de lenitivo á nossa humilhação darem-

\section{TRATADO}

DE

\section{OSTEOLOGIA HUMANA}

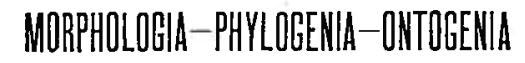

Precedido de noticia docamentada o critice dos professores de anatomia que exerceram em Lisboa desde o seculo xyl até a actualidade

rox

J. A. SERRAN0

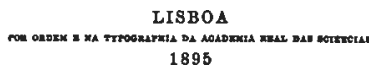

